\title{
Erratum to: Prevention or acceleration of type 1 diabetes by viruses
}

\author{
Liana Ghazarian · Julien Diana • Yannick Simoni • \\ Lucie Beaudoin · Agnès Lehuen
}

Published online: 30 October 2012

(C) Springer Basel 2012

\section{Erratum to: Cell Mol Life Sci}

\section{DOI 10.1007/s00018-012-1042-1}

The original version of this article unfortunately contained errors.

The affiliation was incorrect. The correct author affiliation is as follows:

Université Paris Descartes, Hôpital Saint Vincent de Paul/ Cochin, Bâtiment Petit, 82 Avenue Denfert-Rochereau, 75014 Paris, France.

The acknowledgement section should have included the following text "A. Lehuen is recipient of an APHP-CNRS Contrat Hospitalier de Recherche Translationelle."

The online version of the original article can be found under doi: 10.1007/s00018-012-1042-1.

L. Ghazarian $(\bowtie) \cdot$ J. Diana · Y. Simoni · L. Beaudoin ·

A. Lehuen $(\square)$

Inserm U986, Université Paris Descartes,

Hôpital Saint Vincent de Paul/Cochin, Bâtiment Petit,

82 Avenue Denfert-Rochereau, 75014 Paris, France

e-mail: liana.ghazarian@inserm.fr

A. Lehuen

e-mail: agnes.lehuen@inserm.fr 